\title{
PERLINDUNGAN KONSUMEN ATAS BARANG YANG TIDAK SESUAI DENGAN PERJANJIAN DALAM PERDAGANGAN ELEKTRONIK DIKAITKAN DENGAN UNDANG-UNDANG INFORMASI DAN TRANSAKSI ELEKTRONIK
}

\section{CONSUMER PROTECTION OF INVALID GOODS WITH THE AGREEMENTS OF ELECTRONIC TRADING RELATED TO CONSTITUTION OF ELECTRONIC INFORMATION AND TRANSACTION}

\author{
Herlin Setiani dan \\ Muhammad Taufiq
}

\author{
Program Studi Ilmu Hukum Sekolah Pascasarjana \\ Universitas Djuanda Bogor \\ Jl. Tol Ciawi No. 1, Kotak Pos 35, Bogor 16720. \\ Korespondensi : Herlin Setiani, Telp. - \\ e-mail :
}

Jurnal Living Law, Vol. 10, No.

2, 2018 hlm. 114127

\begin{abstract}
The purpose of this study are: 1) To know and analyze the legal protection of consumers on goods that are not in accordance with the agreement in electronic commerce and 2) the responsibility of business actors in providing compensation for goods that are not in accordance with the agreement in electronic commerce. The research method used is normative juridical research that performs a qualitative approach that sees and analyzes the legal norms in the existing legislation. The results are: 1) Consumer protection of goods is not in accordance with the agreement in electronic commerce, which can be carried out by filing a default, for legal reasons not fulfilled the obligations of business actors in the electronic agreement. The non-fulfillment of this obligation means that there has been a violation of the rights of the other party (the buyer) and the legal consequence is causing the loss, 2) The responsibility of business actors in giving compensation for goods not in accordance with the agreement in electronic trading has not been regulated specifically in UUPK and UU ITE, but principally business actors may be held liable in electronic transactions through contractual liability relating to the loss suffered by consumers.
\end{abstract}

Keywords : Consumer Protection, Agreement, Electronic Transactions.

\begin{abstract}
Abstrak : Tujuan dari penelitian ini yaitu untuk mengetahui dan menganalisis perlindungan hukum terhadap konsumen atas barang yang tak sesuai perjanjian dalam perdagangan elektronik serta tanggung jawab pelaku usaha dalam memberikan ganti rugi atas barang yang tak sesuai dengan perjanjian dalam perdagangan elektronik. Metode penelitian yang dipakai dalam penelitian ini yaitu yuridis normatif dengan melakukan pendekatan kualitatif yang melihat dan menganalisis norma-norma hukum dalam peraturan perundang-undangan yang ada. Hasil dari penelitian ini yaitu: 1) Perlindungan konsumen atas barang tak sesuai dengan perjanjian dalam perdagangan elektronik, yaitu dapat dilaksanakan dengan cara mengajukan gugatan wanprestasi, jika alasan hukum tidak terpenuhinya kewajiban-kewajiban pelaku usaha dalam perjanjian elektronik. Tidak terpenuhinya kewajiban ini berarti telah terjadi pelanggaran hak bagi pihak lain (pembeli) dan akibat hukumnya adalah menimbulkan kerugian, 2) Tanggung jawab pelaku usaha dalam memberikan ganti rugi atas barang yang tidak sesuai dengan perjanjian dalam perdagangan elektronik belum diatur secara spesifik dalam UUPK dan UU ITE, tetapi pada prinsipnya pelaku usaha dapat dituntut pertanggungjawaban dalam transaksi elektronik lewat pertanggungjawaban kontraktual berkaitan dengan kerugian yang dialami oleh konsumen.
\end{abstract}

Kata Kunci : Perlindungan Konsumen, Perjanjian, Transaksi Elektronik. 


\section{PENDAHULUAN}

Pembangunan serta perkembangan perekonomian khususnya pada bidang perindustrian dan juga perdagangan nasional menghasilkan berbagai variasi barang/jasa yang bisa dikonsumsi. Selain itu, globalisasi serta perdagangan bebas yang didukung oleh kemajuan teknologi dan telekomunikasi informatika sudah memperluas ruang gerak arus transaksi barang dan/atau jasa yang ditawarkan bervariasi baik produksi didalam maupun luar negeri. ${ }^{1}$

Perkembangan teknologi menghasilkan berbagai produk barang elektronik yang telah beredar dan diperjual-belikan di pasar. Kondisi yang seperti ini tentunya menguntungkan konsumen karena kebutuhannya terhadap produk barang elektronik dapat terpenuhi terlebih saat produk yang ditawarkan memiliki fungsi, bentuk dan jenis yang bervariasi. Produk barang elektronik menjadi sangat penting karena mampu memberikan kemudahan dan menunjang aktivitas masyarakat. Saat ini dapat diamati secara nyata dari tahun ke tahun semakin banyak pelaku usaha yang memperjual-belikan beranekaragam produk barang elektronik, sejalan dengan hal tersebut masyarakat juga mulai banyak yang memakai produk tersebut. Kondisi seperi ini menggambarkan bahwa dari tahun ke tahun tentu terjadi peningkatan jumlah transaksi terhadap produk barang elektronik itu sendiri.

Kondisi yang demikian itu pada satu pihak memiliki manfaat bagi konsumen sebab kebutuhan konsumen akan barang dan/atau jasa yang dibutuhkan dapat terpenuhi dan semakin terbuka lebar kebebasan untuk memilih aneka jenis dan kuantitas barang dan/atau jasa sesuai dengan keinginan dan kemampuan konsumen.

Keadaan konsumen yang berada dalam posisi lemah ini dimaknai sebagai bagian

1 A. Z. Nasution, Hukum Perlindungan Konsumen Suatu Pengantar, Yogyakarta: Diadit Media, 2001, HIm. 248. dari ketidakmampuan konsumen dalam memahami hak serta kewajiban yang dimilikinya, pandangan ini muncul disebabkan tidak setiap konsumen mempunyai pengetahuan dan juga pemahaman yang sama tentang hak serta kewajiban termasuk hukum perlindungan konsumen.

Kurangnya pengetahuan dan juga pemahaman inilah yang menimbulkan konsumen menjadi suatu objek bisnis untuk mencapai keuntungan yang sebesarbesarnya oleh pelaku usaha. Salah satu bagian perlindungan terhadap konsumen dari perilaku pelaku usaha yang menjadikannya hanya sebagai objek bisnis, sehingga dapat mendatangkan kerugian bagi konsumen adalah melalui pemberian ganti rugi terhadap dari produk cacat yang dikonsumsi atau digunakan oleh konsumen.

Produk cacat di Indonesia diartikan sebagai produk yang tidak dapat memenuhi tujuan pembuatannya baik karena kesengajaan ataupun kealpaan dalam maupun disebabkan hal-hal lain yang terjadi dalam peredarannya, atau tidak menyediakan syarat-syarat keamanan bagi manusia ataupun harta benda mereka dalam penggunaannya, sebagaimana diharapkan konsumen. ${ }^{2}$

Pemberian ganti rugi terdapat dari 3 (tiga) hal, yaitu: ${ }^{3}$

1. Cidera pribadi (termasuk di dalamnya kematian atau gangguan mental);

2. Kerusakan barang pribadi (property); dan

3. Pada beberapa keadaan kehilangan keuntungan ekonomi. Tujuan utamanya adalah memberikan hukuman berupa kewajiban membayar kompensasi kepada konsumen akibat tindakan yang dilakukan oleh produsen.

\footnotetext{
2 Ibid., Hlm. 249.

3 David Oughton and John Lowry, Question \& Answers Law of Torts, London: Blackstone Press Limited, 1999, P. 223.
} 
Ganti kerugian dimaksudkan untuk memulihkan keadaan yang telah menjadi rusak (tidak seimbang akibat adanya penggunaan barang ataupun jasa yang tidak memenuhi harapan konsumen). Hal ini sangat terkait dengan produk yang telah merugikan konsumen baik berupa kerugian materi, maupun kerugian yang menyangkut diri (sakit, cacat, bahkan kematian). ${ }^{4}$

Code Civil Perancis merincikan ganti rugi dalam 2 (dua) unsur yaitu: dommages dan interest. Dommages meliputi apa yang dinamakan biaya dan rugi, sedangkan interest sama dengan bunga dalam arti keuntungan yang diharapkan atau yang sudah diperhitungkan. ${ }^{5}$

Abdulkadir Muhammad mempertegas pernyataan di atas bahwa ganti rugi itu terdiri dari 3 (tiga) unsur, yaitu: 6

1. Ongkos atau biaya yang sudah dikeluarkan, misalnya ongkos cetak, biaya materai, biaya iklan;

2. Kerugian sesungguhnya sebab kerusakan, kehilangan benda milik kreditur, misalnya membusuknya buah-buahan karena keterlambatan penyerahan, ambruknya rumah karena konstruksi, sehingga merusak perabotan rumah tangga;

3. Bunga atau keuntungan yang diharapkan, misalnya bunga berjalan selama piutang terlambat diserahkan (dilunasi), keuntungan yang diperoleh karena keterlambatan.

Keperluan adanya hukum untuk memberikan perlindungan konsumen Indonesia merupakan suatu hal yang tidak bisa dielakkan, sejalan dengan tujuan pembangunan nasional kita, yaitu pembangunan manusia Indonesia seutuhnya. $^{7}$

${ }^{4}$ Ahmadi Miru dan Sutarman Yodo, Op.Cit. Hlm. 126.

5 Riduan Syahrani, Seluk-beluk dan Asas-asas Hukum Perdata, Bandung: Alumni, 2004, Hlm. 223.

6 Abdulkadir Muhammad, Hukum Perdata, Bandung: Citra Aditya Bakti, 2000, HIm. 207.

7 Ibid.
Membahas keperluan hukum untuk memberikan perlindungan bagi konsumen Indonesia, hendaknya terlebih dahulu kita melihat peraturan perundang-undangan di Indonesia, khususnya peraturan atau keputusan yang memberikan perlindungan untuk masyarakat, sehingga bentuk hukum perlindungan konsumen yang ditetapkan sesuai dengan yang diperlukan bagi konsumen Indonesia dan keberadaannya tepat apabila diletakkan di dalam kerangka sistem hukum nasional Indonesia. ${ }^{8}$

Era perdagangan bebas dimana arus barang dan jasa bisa masuk ke semua negara dengan bebas, maka yang semestinya terjadi adalah persaingan jujur. Persaingan jujur adalah suatu persaingan di mana konsumen dapat memiliki barang ataupun jasa karena jaminan kualitas dengan harga yang wajar. Oleh sebab itu pola perlindungan konsumen harus diarahkan pada pola kerjasama antarnegara, antarsemua pihak yang berkepentingan agar terciptanya suatu model perlindungan yang harmonis berdasarkan atas persaingan yang jujur. ${ }^{9}$

Tanggung jawab sosial lebih menekankan kepada pemenuhan hak dan kewajiban baik dan harus dilakukan oleh produsen maupun yang harus dilaksanakan oleh konsumen khususnya dan masyarakat luas pada umumnya. Hak bagi konsumen merupakan kewajiban bagi produsen, kewajiban bagi konsumen merupakan hak bagi produsen, demikian pula sebaliknya. Produsen dalam melakukan komunikasi, selain memperkenalkan dan mempromosikan nama perusahaan dan produk-produk yang ditawarkan, juga mempunyai kewajiban mendidik masyarakat. Dalam melaksanakan kegiatan komunikasi produsen harus menyatakan kondisi yang sebenarnya, baik tentang perusahaan ataupun tentang produk yang ditawarkannya. Demikian pula produsen

\footnotetext{
8 Ibid, Hlm. 8.

${ }^{9}$ Ibid, Hlm. 38.
} 
mempunyai kewajiban untuk mendidik konsumen. ${ }^{10}$

Dengan lembaga ini produsen yang pada awalnya menerapkan strategi product oriented dalam pemasaran produknya harus mengubah strateginya menjadi customer oriented (berorientasi konsumen). Mendeteksi pasar dan menggabungkan customer oriented, jadi dia harus lihat pasar, apa sesuai dengan kemauan pelanggan. Baru dia menemukan apa yang dia bisa sampaikan ke konsumen dan selalu diperkuat. Misalnya, produk yang tidak gampang ditiru. Tidak bisa dipungkiri bahwa barang-barang yang tersedia untuk konsumen tidak selamanya berada dalam kondisi yang sempurna. Dengan kata lain, suatu barang tersebut bisa saja mengandung cacat. Menurut Kamus Besar Bahasa Indonesia cacat bisa diartikan sebagai "kekurangan yang menyebabkan berkurangnya nilai atau mutunya kurang baik atau kurang sempurna". Sesuatu produk dapat disebut cacat (tidak dapat memenuhi tujuan pembuatannya) karena: ${ }^{11}$

1. Cacat produk atau manufaktur, di mana keadaan produk yang umumnya berada di bawah tingkat harapan konsumen. Atau dapat pula cacat itu demikian rupa sehingga dapat membahayakan harta bendanya;

2. Cacat desain, di mana desain produk tidak dipenuhi sebagaimana semestinya, sehingga merugikan konsumen;

3. Cacat peringatan atau industri, di mana produk tidak dilengkapi dengan peringatan-peringatan tertentu atau instruksi penggunaan tertentu.

Jadi, tanggung jawab produk cacat ini beda dari tanggung jawab pelaku usaha produk pada umumnya. Tanggung jawab produk cacat terletak pada tanggung

10 H. Mulyadi Nitisusastro, Perilaku Konsumen Dalam Perspektif Kewirausahaan, Cetakan Kesatu, Bandung: CV. Alfabeta, 2012, HIm. 252.

11 Celina Tri Siwi Kristiyanti, Hukum Perlindungan Konsumen, Jakarta: Sinar Grafika, 2011, Hlm. 103-104. jawab cacatnya produk berakibat pada orang, orang lain atau barang lain, sedang tanggung jawab atas rusaknya atau tidak berfungsinya produk itu sendiri.

Jenis cacat produk itu dapat didefinisikan sebagai suatu produk cacat yang disebabkan oleh satu bentuk kesalahan dalam proses pembuatan produk atau dengan kata lain, apabila suatu produk tidak dibuat sesuai dengan standar kualitas, rencana dan/atau spesifikasi produk yang dibuat oleh produsen itu sendiri seperti misalnya cacat tersembunyi yang terdapat dalam produk elektronik.

Untuk membahas perlindungan hakhak konsumen dari barang yang diproduksi dan diperdagangkan oleh pelaku usaha, maka diperlukan pemahaman secara normatif tentang perbuatan-perbuatan yang dilarang dilakukan oleh pelaku usaha.

Salah satu perubahan yang sangat besar akibat berkembangnya teknologi informasi adalah dalam bidang ekonomi. Pada saat ini dunia perbankan nasional telah banyak yang memanfaatkan fasilitas ini untuk memberikan kemudahan pelayanan dalam melaksanakan kegiatan perbankan bagi nasabahnya dengan menggunakan e-banking atau internet banking.

Melihat potensi dan juga perkembangan e-commerce pada perekonomian Indonesia, Jokowi bersama 4 (empat) menteri mengajak 5 (lima) bos perusahaan e-commerce dalam negeri, yakni Nadiem Makarim (CEO Go-Jek), William Tanuwijaya (Pendiri Tokopedia), Emirsyah Satar (Chairman Matahari Mall.com), Ferry Unardi (Pendiri Traveloka), dan Andrew Darwis (Pendiri Kaskus). Sementara 5 (lima) kapitalis ventura terbesar di dunia ini, di antaranya pemodal besar dari Amerika Serikat, yaitu Sequoia Capital serta Queen of The Net Mary Meeker. Sequoia merupakan perusahaan sukses yang dikenal dengan banyak portofolio investasi, seperti Google, Cisco, Apple, YouTube, WhatsApp, Nvidia, 
Dropbox, PayPal, Yahoo, Oracle, LinkedIn, Airbnb, dan Square. Pertemuan 5 (lima) kapital ventura internasional dan 5 (lima) perusahaan e-commerce yang sukses mencatat nilai kapitalisasi besar dan berpeluang menjadi perusahaan bertaraf internasional12.

Dapat kita lihat pula di Indonesia untuk yang besar, bisa merujuk pada semakin besarnya toko online seperti Bhinneka, Lazada, Olx, Berniaga, Bejubel, Kaskus FJB, dan masih banyak sekali. Sekarang orang juga banyak yang menggunakan Facebook dan Twitter untuk mempromosikan produk mereka, dan hasilnyapun relatif efektif meningkatkan penjualan. Kegiatan $e$ commerce bukan hanya berupa transaksi mengenai jual beli di toko online, akan tetapi juga semua transaksi keuangan di bank yang memanfaatkan internet sebagai medianya. Searah dengan perubahan masyarakat yang sedemikian komplek dalam berbagai dimensinya, aktivitas $e$ commerce membawa implikasi di bidang hukum, yaitu terkait tentang: otentikasi subyek hukum yang membuat transaksi melalui internet, kekuatan mengikat secara hukum, obyek transaksi yang diperjualbelikan, mekanisme peralihan hak, hubungan hukum dan pertanggungjawaban para pihak yang terlibat dalam transaksi, legalitas dokumen catatan elektronik serta tanda tangan digital sebagai alat bukti, mekanisme penyelesaian sengketa, pilihan hukum dan forum peradilan yang berwenang dalam penyelesaian sengketa $e$-commerce.

Berdasarkan latar belakang penelitian yang sudah diuraikan di atas, peneliti mengidentifikasi masalah sebagai berikut:

1. Bagaimana perlindungan hukum terhadap konsumen atas barang yang tidak sesuai dengan perjanjian dalam perdagangan elektronik?

\footnotetext{
12 "Jokowi Boyong 5 Bos Perusahaan E-commerce RI $\mathrm{Ke}$ AS", http://bisnis.liputan6.com/read/2347628/jokowiboyong-5-bos-perusahaan-e-commerce-ri-ke-as>, Diakses pada tanggal 16 Januari 2018.
}

2. Bagaimana tanggung jawab pelaku usaha dalam memberikan ganti rugi atas barang yang tidak sesuai dengan perjanjian dalam perdagangan elektronik?

\section{METODE PENELITIAN}

Metode penelitian yang digunakan dalam penelitian ini adalah pendekatan yuridis normatif, yaitu hukum dikonsepsikan sebagai norma, kaidah, asas atau dogma-dogma/yurisprudensi.

\section{PEMBAHASAN}

\section{A. PERLINDUNGAN HUKUM TERHADAP KONSUMEN ATAS BARANG YANG TIDAK SESUAI DENGAN PERJANJIAN DALAM PERDAGANGAN ELEKTRONIK}

Dewasa ini, perkembangan
perdagangan
tumbuh dengan pesat. Selain membawa
dampak positif bagi perkembangan dan
pertumbuhan perekonomian Indonesia
juga akan menimbulkan permasalahan-
persamalahan yang tentunya harus
ditemukan cara penyelesaiannya
menggunakan peraturan perundang-
undangan yang berlaku di Indonesia.

Bagi masyarakat Indonesia hal ini terkait masalah hukum yang sangat penting. Pentingnya permasalahan hukum di bidang e-commerce adalah terutama dalam memberikan perlindungan terhadap para pihak yang melakukan transaksi melalui internet. 13

Transaksi elektronik yang melibatkan para pihak dari dalam negeri yaitu Negara Indonesia, tidaklah sulit untuk menetapkan aturan hukum yang berlaku apabila terjadi masalah. Secara otomatis the applicable law-nya adalah hukum Indonesia, sehingga baik KUHPerdata maupun Undang-undang No. 8 Tahun 1999 tentang Perlindungan Konsumen dapat

13 Lia Sautunnida, Jual Beli Melalui Internet (ECommerce) Kajian Menurut Buku III KUHPerdata dan Undang-undang Informasi dan Transaksi Elektronik, D.I. Aceh: Fakultas Hukum Universitas Syiah Kuala, 2008, Hlm. 1. 
diterapkan untuk menyelesaikan sengketa yang timbul. Namun bagi transaksi perdagangan lintas negara bukan Negara Indonesia, penyelesaian sengketa akan dilakukan oleh forum yang dipilih oleh para pihak dengan menggunakan hukum yang telah dipilih pula oleh para pihak dalam kontrak elektronik.

Menurut hukum yang berlaku di Indonesia, gugatan perdata bisa didasarkan atas dua alasan, yaitu wanprestasi dan perbuatan melanggar hukum (onrechtmatigedaad). Adapun landasan hukumnya didasarkan pada ketentuan Buku III Pasal 1243 KUHPerdata untuk wanprestasi dan Pasal 1365 KUHPerdata untuk perbuatan melanggar hukum.

Gugatan wanprestasi selalu berawal pada adanya suatu hubungan hukum kontraktual (perjanjian) antara para pihak, sehingga melahirkan hak serta kewajiban hukum. Hak dan kewajiban di sini diwujudkan dengan apa yang dikatakan sebagai prestasi (performance). Pada saat prestasi tak dipenuhi, tidak dilaksanakan, atau dilaksanakan tidak sebagaimana mestinya menurut perjanjian para pihak, maka lahir apa yang dinamakan wanprestasi (cidera janji). Sedangkan pada gugatan perbuatan melanggar hukum, yang menjadi dasar gugatannya adalah kepentingan pihak tertentu yang dirugikan oleh perbuatan pihak lainnya, meskipun di antara para pihak tidak terdapat suatu hubungan hukum keperdataan yang bersifat kontraktual (perjanjian).

Untuk kasus-kasus kerugian konsumen dalam transaksi perdagangan secara elektronik, gugatan akan lebih tepat bila didasarkan atas wanprestasi dan bukan perbuatan melanggar hukum, yaitu dengan merujuk pada kewajibankewajiban sebagai pelaku usaha dalam kontrak elektronik yang telah dilanggar dan karenanya menimbulkan kerugian. Selain penyelesaian secara perdata, pelanggaran dalam transaksi elektronik yang mengandung unsur pidana seperti penipuan juga dapat diproses secara pidana, sebagaimana yang disebutkan dalam Pasal 19 ayat (4) Undang-undang No. 8 Tahun 1999 tentang Perlindungan Konsumen yang menyatakan bahwa "pemberian ganti rugi tidak menghapuskan kemungkinan adanya tuntutan pidana berdasarkan pembuktian lebih lanjut mengenai adanya unsur kesalahan". ${ }^{14}$

Jika kejahatan e-commerce sudah masuk pada ranah pidana maka ketentuan dalam peraturan perundang-undangan Indonesia telah mengaturnya, yakni dalam Undang-undang No. 19 Tahun 2016 tentang Perubahan Atas Undang-undang No. 11 Tahun 2008 tentang Informasi dan Transaksi Elektronik, antara lain dalam Pasal 30 sebagai berikut:

(1) Setiap Orang dengan sengaja dan tanpa hak atau melawan hukum mengakses Komputer dan/atau Sistem Elektronik milik orang lain dengan cara apa pun.

(2) Setiap Orang dengan sengaja dan tanpa hak atau melawan hukum mengakses Komputer dan/atau Sistem Elektronik dengan cara apa pun dengan tujuan untuk memperoleh Informasi Elektronik dan/atau Dokumen Elektronik.

(3) Setiap Orang dengan sengaja dan tanpa hak atau melawan hukum mengakses Komputer dan/atau Sistem Elektronik dengan cara apa pun dengan melanggar, menerobos, melampaui, atau menjebol sistem pengamanan.

Dalam Pasal 8 Undang-undang No. 8 Tahun 1999 tentang Perlindungan Konsumen melarang pelaku usaha untuk memperdagangkan barang/jasa yang tidak sesuai dengan janji yang dinyatakan dalam label, e-tiket, keterangan, iklan atau promosi penjualan barang dan/atau jasa tersebut. Berdasarkan pasal tersebut, ketidaksesuaian spesifikasi barang yang diterima dengan barang tertera pada

14 Rosalinda Elsina Latumahina, Aspek-aspek Hukum Dalam Transaksi Perdagangan Secara Elektronik, Jurnal GEMA AKTUALITA, Vol. 4 No. 1, Juni 2015, Fakultas Hukum Universitas Pelita Harapan Surabaya Surabaya, 2015, Hlm. 50-51. 
iklan/foto penawaran barang adalah bentuk suatu pelanggaran/larangan bagi pelaku usaha dalam memperdagangkan barang. Selaku konsumen sesuai Pasal 4 huruf h Undang-undang No. 8 Tahun 1999 tentang Perlindungan Konsumen tersebut berhak mendapatkan kompensasi, ganti rugi dan/atau penggantian apabila barang dan/atau jasa yang diterima tidak sesuai dengan perjanjian atau tidak sebagaimana mestinya. Sedangkan, pelaku usaha itu sendiri sesuai Pasal 7 huruf g Undang-undang No. 8 Tahun 1999 tentang Perlindungan Konsumen berkewajiban memberi kompensasi, ganti rugi dan/atau penggantian apabila barang dan/atau jasa yang diterima atau dimanfaatkan tidak sesuai dengan perjanjian. Apabila pelaku usaha tidak melaksanakan kewajibannya, pelaku usaha bisa dipidana berdasarkan Pasal 62 Undang-undang No. 8 Tahun 1999 tentang Perlindungan Konsumen, yang bunyinya: Pelaku usaha yang melanggar ketentuan sebagaimana dimaksud dalam Pasal 8, Pasal 9, Pasal 10, Pasal 13 ayat (2), Pasal 15, Pasal 17 ayat (1) huruf a, huruf b, huruf c, huruf e, ayat (2) dan Pasal 18 dipidana dengan pidana penjara paling lama 5 (lima) tahun atau pidana denda paling banyak Rp 2.000.000.000,00 (dua milyar rupiah).

Persetujuan untuk membeli barang secara online dengan cara melakukan klik persetujuan atas transaksi merupakan bentuk tindakan penerimaan yang menyatakan persetujuan dalam kesepakatan pada transaksi elektronik. Tindakan penerimaan tersebut biasanya didahului pernyataan persetujuan atas syarat dan ketentuan jual beli secara online yang dapat dikatakan juga sebagai salah satu bentuk Kontrak Elektronik. Kontrak Elektronik berdasarkan Pasal 47 ayat (2) Peraturan Pemerintah No. 82 Tahun 2012 tentang Penyelenggaraan Sistem dan Transaksi Elektronik, dianggap sah apabila:

a. Terdapat kesepakatan para pihak;

b. Dilakukan oleh subjek hukum yang cakap atau yang berwenang mewakili sesuai dengan ketentuan peraturan perundang-undangan;

c. Terdapat suatu hal tertentu; dan

d. Objek transaksi tak boleh bertentangan dengan peraturan perundangundangan, kesusilaan, dan ketertiban umum.

Kontrak Elektronik sendiri menurut Pasal 48 ayat (3) Peraturan Pemerintah No. 82 Tahun 2012 tentang Penyelenggaraan Sistem dan Transaksi Elektronik, setidaknya harus memuat hal-hal sebagai berikut:

a. Data identitas para pihak;

b. Objek dan spesifikasi;

c. Persyaratan Transaksi Elektronik;

d. Harga dan biaya;

e. Prosedur dalam hal terdapat pembatalan oleh para pihak;

f. Ketentuan yang memberikan hak kepada pihak yang dirugikan untuk bisa mengembalikan barang dan/atau meminta penggantian produk apabila terdapat cacat tersembunyi; dan

g. Pilihan hukum penyelesaian Transaksi Elektronik.

Dengan demikian, pada transaksi elektronik yang dilakukan, konsumen dapat menggunakan instrumen Undangundang No. 19 Tahun 2016 tentang Perubahan Atas Undang-undang No. 11 Tahun 2008 tentang Informasi dan Transaksi Elektronik dan/atau Peraturan Pemerintah No. 82 Tahun 2012 tentang Penyelenggaraan Sistem dan Transaksi Elektronik sebagai dasar hukum dalam menyelesaikan permasalahan e-commerce.

Perbuatan sebagaimana dijelaskan di dalam Pasal 28 ayat (1) Undang-undang No. 19 Tahun 2016 tentang Perubahan Atas Undang-undang No. 11 Tahun 2008 tentang Informasi dan Transaksi Elektronik diancam dengan pidana penjara paling lama 6 (enam) tahun dan/atau denda paling banyak Rp. 1 miliar (Pasal 45 ayat (2) UU ITE). Berdasarkan hal-hal tersebut di atas, penyelesaian sengketa dalam transaksi perdagangan secara elektronik bisa dilakukan secara perdata maupun 
pidana, sehinga memberikan payung hukum kepada masayarakat di Indonesia.

Contoh kasus, salah satu konsumen transaksi elektronik pernah tertipu oleh bisnis jual beli on line ini. Saudara $\mathrm{X}$ pernah mengalami kasus penipuan dalam transaksi elektronik. Saudara X merupakan konsumen online shop, membeli sebuah handphone bermerek Samsung, melalui situs Lazada.co.id. informasi yang disampaikan dalam situs ini menyebutkan bahwa Samsung yang dijual adalah jenis Acord 2 seharga Rp. 1.500.000,- dengan menampilkan contoh barang yang dijual. Semua berjalan sesuai prosedur, Saudara X menyepakati barang yang dibeli, memberitahu alamat detail pengiriman, membayar sesuai kesepakatan yaitu Rp. 1.500.000, serta memberikan konfirmasi kepada pihak online shop bahwa telah melakukan pembayaran dengan menunjukkan bukti foto kuitansi ATM. Namun pihak pelaku usaha tidak bersedia mengirimkan barang dengan alasan pihak pelaku usaha akan mengirimkan barang apabila Saudara $X$ sebagai konsumen membeli barang tersebut 2 (dua) buah. Padahal kesepakatan awal Saudara X akan membeli sebuah Samsung, namun setelah proses pembayaran terjadi, pihak pelaku usaha mengelak untuk mengirimkan barangnya.

Adanya kesalahan informasi dari pelaku usaha online shop ini membuat Saudara X mengalami kerugian. Untuk memperjuangkan haknya, Saudara X berusaha menelepon pelaku usaha meminta uangnya dikembalikan, namun ternyata nomor telepon si penjual sudah tidak aktif lagi. Setelah kejadian ini Saudara $\mathrm{X}$ memilih untuk pasrah tanpa melaporkan kejadian yang menimpanya ke pihak yang berwenang.

Dalam Pasal 4 huruf e Undang-Undang No. 8 Tahun 1999 tentang Perlindungan Konsumen diatur tentang hak konsumen yaitu hak untuk mendapatkan advokasi, perlindungan, juga upaya penyelesaian sengketa perlindungan konsumen secara patut. Namun dalam kasus di atas, Saudara
$\mathrm{X}$ sebagai konsumen tidak menggunakan haknya dengan sebagaimana mestinya. Pasal 45 ayat (1) Undang-undang No. 8 Tahun 1999 tentang Perlindungan Konsumen ini juga menyebutkan bahwa setiap konsumen yang dirugikan bisa menggugat pelaku usaha lewat lembaga yang bertugas menyelesaikan sengketa antara konsumen dan pelaku usaha atau lewat peradilan yang berada di lingkungan peradilan umum. Bahwa secara jelas telah diatur pada dalam undang-undang mengenai hak konsumen yang melekat pada Saudara X serta mereka juga bisa menggugat pelaku usaha yang merugikan mereka ${ }^{15}$.

\section{B. TANGGUNG JAWAB PELAKU USAHA DALAM MEMBERIKAN GANTI RUGI ATAS BARANG YANG TIDAK SESUAI DENGAN PERJANJIAN DALAM PERDAGANGAN ELEKTRONIK}

Untuk mengetahui bagaimanakah tanggung jawab pelaku usaha memberikan ganti rugi atas kerusakan barang kepada konsumen, maka diperlukan pemahaman secara normatif tentang bentuk-bentuk pertanggungjawaban oleh pelaku usaha terhadap konsumen yang merasa dirugikan akibat adanya kerusakan barang.

Undang-undang No. 8 Tahun 1999 tentang Perlindungan Konsumen, ternyata memberikan pemahaman secara normatif pelaksanaan tanggung jawab pelaku usaha untuk memberikan ganti rugi akibat kerusakan, pencemaran, dan/atau kerugian konsumen harus dilaksanakan sebagaimana diatur dalam Pasal 19 ayat (1) (2) (3) dan (4) dengan tidak menutup kemungkinan kewajiban ganti rugi oleh pelaku usaha tidak perlu dilakukan terhadap konsumen, apabila pelaku usaha mampu membuktikan penyebab kerusakan barang bukanlah karena kesalahan pelaku usaha melainkan konsumen sendiri, sebagaimana diatur dalam ayat (5). 
Secara umum prinsip-prinsip tanggung jawab dalam hukum bisa dibedakan sebagai berikut:

a. Kesalahan;

b. Praduga selalu bertanggung jawab (presumption based on fault);

c. Praduga selalu tidak bertanggung jawab (presumption of nonliability);

d. Tanggung jawab mutlak (strict liability);

e. Pembatasan tanggung jawab (limitation of liability). ${ }^{16}$

Prinsip praduga selalu bertanggung jawab. Prinsip ini menyatakan, tergugat selalu dianggap bertanggung jawab (presumption of liability principle) sampai saat ini ia dapat membuktikan ia tidak bersalah, jadi beban pembuktian ada pada si tergugat. ${ }^{17}$ Prinsip praduga untuk tidak selalu bertanggung jawab. Prinsip ini adalah kebalikan dari prinsip kedua. Prinsip praduga untuk tidak selalu bertanggung jawab (presumption nonliability principle) hanya dikenal dalam lingkup transaksi konsumen yang sangat terbatas dan pembatasan demikian biasanya secara common sense dapat dibenarkan. Contoh dalam penerapan prinsip ini ialah dalam hukum pengangkutan. Kehilangan atau kerusakan pada bagasi/bagasi tangan yang biasanya dibawa dan diawasi oleh si penumpang (konsumen) adalah tanggung jawab dari penumpang. Dalam hal ini, pengangkut (pelaku usaha) tidak dapat diminta pertanggungjawaban. ${ }^{18}$

Prinsip tanggung jawab mutlak (strict liability) sering diidentikkan dengan prinsip tanggung jawab absolute (absolute liability), kendati demikian ada pula para ahli yang membedakan kedua terminologi di atas. Ada pendapat yang mengatakan strict liability adalah prinsip tanggung jawab yang menetapkan kesalahan tidak sebagai faktor yang menentukan, namun ada pengecualianpengecualian yang memungkinkan untuk dibebaskan dari tanggung jawab, misalnya keadaan force majeur. Sebaliknya, absolute liability adalah prinsip tanggung jawab tanpa kesalahan dan tidak ada pengecualiannya. Selain itu ada pandangan yang agak mirip yang mengaitkan perbedaan keduanya pada ada atau tidak adanya hubungan kausalitas antara subjek yang bertanggung jawab dan kesalahannya. Pada strict liability, hubungan itu harus ada, sementara pada absolute liability, hubungan itu tidak selalu ada. Maksudnya pada absolute liability, dapat saja si tergugat yang dimintai pertanggungjawaban itu bukan si pelaku langsung kesalahan tersebut (misalnya dalam kasus bencana alam). ${ }^{19}$

Tanggung jawab pelaku usaha ini telah diatur dalam Pasal 19 sampai dengan Pasal 28 Undang-undang No. 8 Tahun 1999 tentang Perlindungan Konsumen. Berdasarkan undang-undang tersebut, bukan hanya pelaku usaha yang bertanggung jawab terhadap barang dan/atau jasa yang dihasilkan ataupun diperdagangkannya, tetapi termasuk juga importir.

Pasal 19 Undang-undang No. 8 Tahun 1999 tentang Perlindungan Konsumen mengatur tanggung jawab kesalahan pelaku usaha terhadap produk yang dihasilkan ataupun diperdagangkannya. Dikatakan pelaku usaha bertanggung jawab memberikan ganti rugi atas:

a. Kerusakan;

b. pencemaran;

c. kerusakan dan kerugian konsumen;

d. kerugian konsumen. ${ }^{20}$

Akibat mengkonsumsi barang dan/atau jasa yang dihasilkan atau diperdagangkan. Bentuk ganti rugi berupa:

a. Pengembalian uang;

b. Penggantian barang dan/atau jasa yang sejenis atau setara;

c. Perawatan kesehatan dan/atau pemberian santunan yang sesuai

19 Ibid, Hlm. 96.

\footnotetext{
20 Ibid, Hlm. 218.
}

\footnotetext{
16 Celina Tri Siwi Kristiyanti, Op.Cit, Hlm. 92.

17 Ibid, Hlm. 94.

18 Ibid, Hlm. 95-96.
} 
dengan ketentuan peraturan perundang-undangan yang berlaku. ${ }^{21}$

Tanggung jawab pelaku usaha dalam memberikan ganti rugi di atas tidak berlaku apabila pelaku usaha dapat membuktikan bahwa kesalahan tersebut merupakan kesalahan konsemen. Ini berarti bahwa pembuktian terhadap ada tidaknya unsur kesalahan dalam gugatan ganti rugi merupakan beban dan tanggung jawab pelaku usaha. ${ }^{22}$

Tanggung jawab untuk memberikan ganti rugi kepada konsumen, lebih ditegaskan dalam Undang-undang No. 8 Tahun 1999 tentang Perlindungan Konsumen, sebagaimana disebutkan dalam Pasal 63. Undang-undang No. 8 Tahun 1999 tentang Perlindungan Konsumen, mengatur mengenai Sanksi Administratif 23 .

Tanggung gugat produk merupakan terjemahan bebas dalam bahasa Indonesia yang secara populer sering disebut dengan "product liability" adalah suatu konsepsi hukum yang intinya dimaksudkan memberikan perlindungan kepada konsumen yaitu dengan jalan memberikan perlindungan konsumen dari beban untuk membuktikan bahwa kerugian konsumen timbul akibat kesalahan dalam proses produksi dan sekaligus ganti rugi. ${ }^{24}$

Pada dasarnya konsepsi tanggung gugat produk ini secara umum tidak jauh berbeda dengan konsepsi tanggung jawab sebagaimana diatur dalam ketentuan Pasal 1365 dan Pasal 1865 KUHPerdata. Perbedaannya adalah bahwa tanggung jawab produsen untuk memberikan ganti rugi diperoleh, setelah pihak yang menderita kerugian bisa membuktikan bahwa cacatnya produk tersebut serta kerugian yang timbul merupakan akibat kesalahan yang dilakukan produsen. Perbedaan lain, yaitu bahwa ketentuan ini tidak secara tegas mengatur pemberian ganti rugi ataupun beban pembuktian

\footnotetext{
21 Ibid.

22 Ibid.

23 Pasal 60

${ }^{24}$ Nurmadjito, Op.Cit, Hlm. 22.
}

kepada konsumen, melainkan kepada pihak manapun yang mempunyai hubungan hukum dengan produsen, apakah sebagai konsumen, sesama produsen penyalur, pedagang atau instansi lain, sehingga sebagai suatu konsep, materi tanggung gugat produk yang pada hakikatnya termasuk doktrin hukum yang masih baru merupakan salah satu upaya untuk memperkaya khasanah dalam sistem hukum yang selama ini berlaku di Indonesia. ${ }^{25}$

Faktor utama yang menjadi kelemahan konsumen adalah tingkat kesadaran konsumen akan haknya masih rendah. Hal tersebut terutama disebabkan oleh rendahnya pendidikan konsumen. Oleh karena itu, Undang-undang No. 8 Tahun 1999 tentang Perlindungan Konsumen dimaksudkan menjadi landasan hukum yang kuat bagi pemerintah dan lembaga perlindungan konsumen swadaya masyarakat untuk melakukan upaya pemberdayaan konsumen melalui pembinaan dan pendidikan konsumen. Upaya pemberdayaan ini penting karena tidak mudah mengharapkan kesadaran pelaku usaha yang pada dasarnya prinsip ekonomi pelaku usaha adalah mendapat keuntungan yang semaksimal mungkin dengan modal seminimal mungkin. Prinsip ini sangat potensial merugikan kepentingan konsumen, baik secara langsung maupun tidak langsung. ${ }^{26}$

Atas dasar kondisi sebagaimana dipaparkan di atas, perlu upaya pemberdayaan konsumen melalui pembentukan undang-undang yang dapat melindungi kepentingan konsumen secara integratif dan komprehensif serta bisa diterapkan secara efektif di masyarakat. Piranti hukum yang melindungi konsumen tidak dimaksudkan untuk mematikan usaha para pelaku usaha, tetapi justru sebaliknya perlindungan konsumen dapat mendorong iklim berusaha yang sehat yang mendorong lahirnya perusahaan

25 Ibid., Hlm. 23.

26 Ibid. 
yang tangguh dalam menghadapi persaingan lewat penyediaan barang dan/atau jasa yang berkualitas.

Dengan demikian, mengenai ganti rugi oleh pelaku usaha merupakan upaya hukum untuk mencegah terjadinya pelanggaran atas hak-hak konsumen dan sebagai pertanggungjawaban hukum yang harus dipatuhi dan dilaksanakan oleh pelaku usaha dalam hubungannya dengan konsumen. Diharapkan bagi pelaku usaha untuk bersikap jujur dan beritikad baik dalam menjalankan usahanya, sehingga barang yang diproduksi dan diperdagangkan tidak merugikan konsumen yang memakainya dan hal ini tentunya akan meningkatkan kepercayaan konsumen terhadap barang yang diproduksi dan/atau diperdagangkan oleh pelaku usaha. Hal ini akan menciptakan iklim usaha yang kondusif bagi pelaku usaha, karena kepercayaan konsumen merupakan bagian dari wujud tanggung jawab pelaku usaha dalam menjalankan usahanya.

Transaksi jual beli yang dilakukan secara online, berdasarkan Undang-undang Nomor 19 Tahun 2016 tentang Perubahan Atas Undang-undang Nomor 11 Tahun 2008 tentang Informasi dan Transaksi Elektronik dan/atau Peraturan Pemerintah Nomor 82 Tahun 2012 tentang Penyelenggaraan Sistem dan Transaksi Elektronik tetap diakui sebagai transaksi elektronik yang dapat dipertanggung jawabkan. Persetujuan untuk membeli barang secara online dengan cara melakukan klik persetujuan atas transaksi merupakan bentuk tindakan penerimaan yang menyatakan persetujuan dalam kesepakatan pada transaksi elektronik. Tindakan penerimaan tersebut biasanya didahului pernyataan persetujuan atas syarat dan ketentuan jual beli secara online yang bisa dinayatakan juga sebagai salah satu bentuk Kontrak Elektronik. Kontrak Elektronik menurut Pasal 47 ayat (2) Peraturan Pemerintah No. 82 Tahun 2012 tentang Penyelenggaraan Sistem dan Transaksi Elektronik dianggap sah apabila:
1. Terdapat kesepakatan para pihak.

2. Dilakukan oleh subjek hukum yang cakap atau yang berwenang mewakili sesuai dengan ketentuan peraturan perundang-undangan.

3. Terdapat hal tertentu.

4. Objek transaksi tidak boleh bertentangan dengan peraturan perundang-undangan, kesusilaan, dan ketertiban umum.

Dengan demikian, pada transaksi elektronik yang dilakukan dapat menggunakan instrument Undang-undang Nomor 19 Tahun 2016 tentang Perubahan Atas Undang-undang No. 11 Tahun 2008 tentang Informasi dan Transaksi Elektronik dan/atau Peraturan Pemerintah Nomor 82 Tahun 2012 tentang Penyelenggaraan Sistem dan Transaksi Elektronik sebagai dasar hukum dalam menyelesaikan permasalah. Terkait dengan perlindungan konsumen, Pasal 49 ayat (1) Peraturan Pemerintah No. 82 Tahun 2012 tentang Penyelenggaraan Sistem dan Transaksi Elektronik menegaskan bahwa pelaku usaha yang menawarkan produk melalui sistem elektronik wajib menyediakan informasi yang lengkap dan juga benar berkaitan dengan syarat kontrak, produsen, dan produk yang ditawarkan. Pasal ayat berikutnya lebih ditegaskan lagi bahwa pelaku usaha wajib memberikan kejelasan informasi tentang penawaran kontrak atau iklan.

Pasal 49 ayat (3) Peraturan Pemerintah No. 82 Tahun 2012 tentang Penyelenggaraan Sistem dan Transaksi Elektronik mengatur khusus tentang hal: yakni pelaku usaha wajib memberikan batas waktu kepada konsumen untuk mengembalikan barang yang dikirim jika tidak sesuai dengan perjanjian atau terdapat cacat tersembunyi.

Selain kedua ketentuan tersebut di atas, apabila ternyata barang yang diterima tidak sesuai dengan foto pada iklan toko online tersebut, maka dapat menggugat pelaku usaha secara perdata dengan dalih terjadinya wanpretasi atas 
transaksi jual beli yang dilakukan dengan penjual.

\section{KESIMPULAN}

Berdasarkan hasil penelitian dan pembahasan di atas, penulis dapat mengambil kesimpulan, sebagai berikut:

1. Perlindungan konsumen atas barang yang tidak sesuai dengan perjanjian dalam perdagangan elektronik, yaitu dapat dilakukan dengan cara mengajukan gugatan wanprestasi, dengan alasan hukum tidak terpenuhinya kewajiban-kewajiban pelaku usaha dalam perjanjian elektronik. Tidak terpenuhinya kewajiban ini berarti telah terjadi pelanggaran hak bagi pihak lain (pembeli) dan akibat hukumnya adalah menimbulkan kerugian. Perlindungan hukum didasarkan pada UU ITE dan UUPK, regulasi ini memberikan payung hukum terhadap orang-orang yang merasa dirugikan terhadap kegiatan e-commerce. Pengesahan UU ITE pada Tahun 2008 merupakan bentuk dari keseriusan Indonesia untuk memberikan kepastian hukum kepada masyarakat terkait dengan sengketa-sengketa yang terjadi melalui media teknologi informasi, yang bermuara pada pencapaian nilai keadilan serta kemanfaatan.

2. Tanggung jawab pelaku usaha dalam memberikan ganti rugi atas barang yang tidak sesuai dengan perjanjian dalam perdagangan elektronik belum diatur secara spesifik dalam UUPK dan UU ITE, tetapi pada prinsipnya pelaku usaha bisa dituntut pertanggungjawaban pada transaksi elektronik lewat pertanggungjawaban kontraktual (contractual liability) berkaitan dengan kerugian yang dialami oleh konsumen. Pertanggungjawaban produk (product liability) jika ternyata produk yang ditawarkan oleh pelaku usaha cacat dan merugikan konsumen. Pada kenyataannya tuntutan tanggungjawab pada pelaku usaha masih mengalami hambatan sebab diterapkannya perjanjian baku dalam kontrak dan perlunya pembuktian untuk menuntut pertanggungjawaban pelaku usaha dalam transaksi internet cukup panjang dan juga berbelit-belit.

\section{SARAN}

1. Revitalisasi fungsi Lembaga Perlindungan Konsumen di Indonesia sebagai mitra Komisi Pengawas Perdagangan Online, pelanggaran pada bidang e-commerce dapat diminimalisasi, guna mencapai keadilan, kepastian hukum dan kemanfaatan, sehingga tercapai kesejahteraan bagi seluruh lapisan masyarakat.

2. Tanggung jawab pelaku usaha memberikan ganti rugi atas kerusakan barang yang diperdagangkan oleh pelaku usaha perlu dibuktikan secara hukum mengenai unsur kesalahannya dan pelaksanaan ganti rugi harus sesuai dengan ketentuan-ketentuan yang berlaku baik melalui penyelesaian sengketa di pengadilan maupun di luar pengadilan. Pelaku usaha harus dibebaskan dari tanggunggjawab apabila tidak terbukti unsur kesalahannya atau karena kesalahan konsumen sehingga barang yang digunakan dalam keadaan rusak. 


\section{UCAPAN TERIMA KASIH}

\section{DAFTAR PUSTAKA}

\section{A. Buku:}

Abdulkadir Muhammad, Hukum Perdata, Bandung: Citra Aditya Bakti, 2000.

Ahmadi Miru dan Sutarman Yodo, Hukum Perlindungan Konsumen, Jakarta: Rajawali Pers, 2005.

Az. Nasution, Hukum Perlindungan Konsumen Suatu Pengantar, Yogyakarta: Diadit Media, 2001.

Celina Tri Siwi Kristiyanti, Hukum Perlindungan Konsumen, Jakarta: Sinar Grafika, 2011.

David Oughton and John Lowry, Question \& Answers Law of Torts, London: Blackstone Pres Limited, 1999.

Erman Rajagukguk, dkk, Hukum Perlindungan Konsumen, Cetakan l, Bandung: Mandar Maju Bandung, 2000.

Gunawan Widjaja dan Ahmad Yani, Hukum tentang Perlindungan Konsumen, Jakarta: Gramedia Pustaka Utama, 2000.

H. Mulyadi Nitisusastro, Perilaku Konsumen Dalam Perspektif Kewirausahaan, Cetakan Kesatu, Bandung: CV. Alfabeta, 2012.

Janus Sidabalok, Hukum Perlindungan Konsumen di Indonesia, Bandung: Citra Aditya Bakti , 2006.

Lia Sautunnida, Jual Beli Melalui Internet (E-Commerce) Kajian Menurut Buku III KUHPerdata dan Undang-undang Informasi dan Transaksi Elektronik, D.I. Aceh: Fakultas Hukum Universitas Syiah Kuala, 2008.

Riduan Syahrani, Seluk-beluk dan Asas-asas Hukum Perdata, Bandung: Alumni, 2004.

Usman Rachmadi, Hukum Ekonomi Dalam Dinamika, Cet. I, Jakarta: Djambatan, 2000.

\section{B. Peraturan Perundang-undangan}

UU Dasar Negara Republik Indonesia Tahun 1945.

Kitab Undang-undang Hukum Perdata.

Undang-undang No.8 Tahun 1999 tentang Perlindungan Konsumen. 
Undang-undang No.19 Tahun 2016 tentang Perubahan atas Undang-undang No. 11 Tahun 2008 tentang Informasi dan Transaksi Elektronik.

Peraturan Pemerintah No. 82 Tahun 2012 tentang Penyelenggaraan Sistem dan Transaksi Elektronik.

\section{Jurnal Hukum}

Emilda Kuspraningrum, Keabsahan Kontrak Elektronik Dalam UU ITE Ditinjau Dari Pasal 1320 KUHPerdata dan UNCITRAL Model Law On Electronic Commerce, Risalah HUKUM Fakultas Hukum Unmul Vol. 7, No. 2, Desember 2011.

Rosalinda Elsina Latumahina, Aspek-aspek Hukum Dalam Transaksi Perdagangan Secara Elektronik, Jurnal GEMA AKTUALITA, Vol. 4 No. 1, Juni 2015, Fakultas Hukum Universitas Pelita Harapan Surabaya Surabaya, 2015.

\section{Internet}

“Jokowi Boyong 5 Bos Perusahaan E-commerce RI Ke AS", http://bisnis.liputan6.com/read/2347628/jokowi-boyong-5-bos-perusahaan-ecommerce-ri-ke-as>, Diakses pada tanggal 16 Januari 2018 